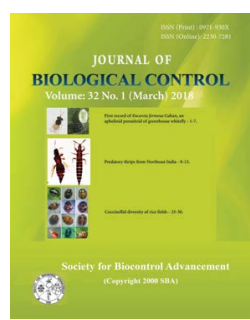

Research Article

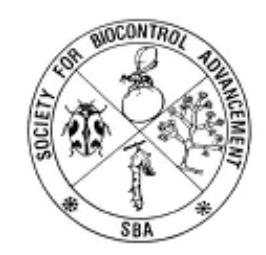

\title{
Susceptibility of white grub, Brahmina coriacea (Hope) infesting potato to local strains of Beauveria brongniartii (Saccardo) in Himachal Pradesh
}

\author{
SAURBH SONI*, P. K. MEHTA and R. S. CHANDEL \\ Department of Entomology, CSK Himachal Pradesh Krishi Vishvavidyalya Palampur - 176062, Himachal Pradesh, India \\ *Corresponding author E-mail: saurbhsoni@gmail.com
}

\begin{abstract}
Brahmina coriacea (Hope) is the most widely distributed and destructive species of white grubs having potential to inflict 40-50 per cent yield losses to potato in Himachal Pradesh. The efficacy of two local isolates of Beauveria brongniartii (KH I and KH II) was evaluated against grubs of $B$. coriacea by dip treatment and oral feeding methods. Against first and second instar grubs, KH I in dip treatment proved to be highly effective, whereas for third instar grubs, KH I through oral feeding showed higher virulence. The $\mathrm{LC}_{50}$ values for first instar grubs for $\mathrm{KH} \mathrm{I}$ and $\mathrm{KH}$ II were $2.55 \times 10^{5}$ conidia $/ \mathrm{ml}$ and $2.80 \times 10^{5}$ conidia/ml in dip treatment, whereas in oral feeding method, the $\mathrm{LC}_{50}$ values were $7.27 \times 10^{5}$ conidia $/ \mathrm{ml}$ and $9.69 \times 10^{5}$ conidia $/ \mathrm{ml}$, respectively. Against second instar grubs, $\mathrm{LC}_{50}$ values calculated were $2.91 \times 10^{5}$ conidia $/ \mathrm{ml}$ and $3.98 \times 10^{5}$ conidia $/ \mathrm{ml}$ for $\mathrm{KH} \mathrm{I}$ and $\mathrm{KH}$ II in dip treatment, whereas corresponding values through oral feeding method were $5.36 \times 10^{5}$ conidia $/ \mathrm{ml}$ and $8.82 \times 10^{5}$ conidia $/ \mathrm{ml}$. $\mathrm{C}_{50}$ values for third instar grubs were $4.47 \times 10^{5} \mathrm{conidia} /$ $\mathrm{ml}$ and $4.88 \times 10^{5}$ conidia $/ \mathrm{ml}$ for KH I and KH II in dip treatment, whereas through oral feeding, $\mathrm{LC}_{50}$ values were $3.03 \times 10^{5} \mathrm{conidia} / \mathrm{ml}$ and $5.14 \times 10^{5}$ conidia/ml for KH I and KH II, respectively.
\end{abstract}

KEY WORDS: Brahmina coriacea, Beauveria brongniartii, Himachal Pradesh, potato, susceptibility

(Article chronicle: Received: 16-06-2017; Revised: 21-02-2018; Accepted: 03-03-2018)

\section{INTRODUCTION}

The larvae of family Scarabaeidae are recognized as pests of planted crops in many parts of the world and are almost universally known as 'white grubs'. In India, the white grubs have been categorized as a national pest and form a major component both in number of species and diversity of habits (Veeresh, 1988). The most widely distributed and destructive species in India are Brahmina coriacea (Hope), Anomala dimidiata Hope, Holotrichia longipennis $\mathrm{Bl}, H$. consanguinea $\mathrm{Bl}$, H. serrata (Fab.) and Lepidiota mansueta Burmeister. Brahmina coriacea has been recorded from most of the north western Indian hills occupying Himachal Pradesh, Uttrakhand and Jammu \& Kashmir (Chandel et al., 2015). In Himachal Pradesh, B. coriacea is the most predominant species constituting about 90 per cent of the total beetle population in higher hills (Chandel et al., 2003).

In potato, the problem of white grubs is quite serious in hilly states where potatoes are grown during summer season as rain fed crop (Misra and Chandel, 2003). In higher hills of Uttar Pradesh, Himachal Pradesh, Jammu \& Kash- mir and north eastern states, white grubs are responsible for causing 40-90 per cent losses in potato yield (Misra, 2000). Besides potato, other cultivated crops such as maize, rice, vegetable, rajmah, ginger and fruit crops are also attacked by white grubs (Chandel et al., 2015b). In majority of farming situations, control of these pests have become increasingly difficult because of the lack of control over the damages they cause. Application of chemical is practically uneconomical, difficult and associated with high cost, environmental pollution and other problems. Among alternative strategies for the control of white grubs, entomopathogenic fungi constitute a potential group of biocontrol agents in the integrated management of white grubs because the pest activity period provides ideal humid conditions for their proliferation (Srikanth et al., 2010). Among them, Beauveria is one of the most studied fungi which infect many insect species in different parts of the world (Hajek and St. Leger, 1994). Beauveria exists saprophytically in the soil and often causes widespread epizootics wiping out insect populations on crops (Leathers et al., 1993). Three species of Beauveria, viz., B. bassiana (Balsamo), B. brongniartii (Saccardo) 
and B. amorpha (von Hoehnel) are active against white grubs (Gupta, 2001). Entomopathogens of native region are of paramount importance in managing soil pests, as they sustain themselves in soil, after proper establishment. $B$. brongniartii is of great importance and can be effectively utilized as one of the components in the management of white grubs in summer planted potatoes. Susceptibility of insect developmental stages to entomopathogenic fungi is a key point in developing a control strategy. In the present study, we investigated the pathogenecity of two isolates of the $B$. brongniartii native to Himachal Pradesh against various larval instars of $B$. coriacea.

\section{MATERIALS AND METHODS}

\section{Isolation and maintenance of Beauveria brongniartii}

Beauveria brongniartii was isolated from the diseased grubs of $B$. coriacea from the potato fields. The diseased grubs showed white mycelial growth on their body and such grubs were collected in screw cap vials and brought to laboratory for isolation of the fungus. The fungus infected grubs were surface sterilized by immersing them into $5 \%$ sodium hypochloride solution for 2 minutes and then rinsed with sterile distilled water thrice under aseptic conditions. The sterilized specimen was cut open in a sterile Petri plate and a small portion of infected tissue was streaked on Potato Dextrose Agar (PDA) slants. The slants were kept at $26 \pm 1^{\circ} \mathrm{C}$. The fungus was identified by Dr YS Paul, Senior Mycologist, Department of Plant Pathology, CSKHPKV Palampur.

\section{Maintenance of insect culture in laboratory}

Adult beetles of Brahmina coriacea were collected from apple orchards during late evening hours around 8:00 PM onwards near the host trees in Shimla hills during midJune. Beetles were reared in glass jars on fresh pear twigs provided with about $15 \mathrm{~cm}$ soil layer at bottom for oviposition. Eggs were separated from jars and transferred to Petri dishes containing moist soil. Newly emerged grubs were transferred to small paper cups containing 4-5 days old maize seedlings. Second and third instar grubs were reared on potato tubers.

\section{Inoculation and treatment of Brahmina coriacea grubs for bioassay studies}

A laboratory experiment was conducted to determine the virulence of $B$. brongniartii on first, second and third instar grubs of $B$. coriacea. Fungal isolates collected from Kheradhar and coded as KH I and KH II were tested by dip treatment and by oral feeding methods. There were 7 treatments ( 6 conidial suspension and a check) each replicated thrice with 15 larvae/replicate. The conidia were harvested by adding $10 \mathrm{ml}$ of sterile distilled water in PDA slants containing 20 days old well sporulated culture. The conidial count was taken through haemocytometer and different conidial suspensions ranging from 9.5 to $0.5 \times 10^{5}$ conidia $/ \mathrm{ml}$ were prepared in sterilized distilled water. The concentration of stock solution was $9.5 \times 10^{5}$ conidia/ml, and further concentrations were obtained through serial dilution method. For obtaining concentration of $7.5 \times 10^{5}$ conidia $/ \mathrm{ml}, 79$ $\mathrm{ml}$ of stock solution was taken and final volume of $100 \mathrm{ml}$ was prepared by adding sterilized distilled water. To make lower concentrations of 5.5, 3.5, 1.5 and $0.5 \times 10^{5}$ conidia/ $\mathrm{ml}, 73 \mathrm{ml}, 64 \mathrm{ml}, 43 \mathrm{ml}$ and $33 \mathrm{ml}$ suspension was taken from each serial dilution, and final volume was prepared to $100 \mathrm{ml}$ using distilled water, respectively.

\section{Dip treatment}

The first and second instar grubs were dipped for about 10 seconds in the conidial suspension@1 @1/grub in Petri plate, whereas for dip treatment of third instar grubs, the volume was standardized to $5 \mathrm{ml} / \mathrm{grub}$. Treated grubs were immediately placed in paper cups containing moist sterilized soil. First instar grubs were released in cups containing 4-5 days old maize seedlings. However, for second and third instar grubs, small potato tubers were put in soil.

\section{Oral feeding method}

For first instar grubs, maize roots were dipped in conidial suspension, whereas for second and third instar grubs, small potato tubers were treated. After treatment, maize seedlings were given to first instar grubs and potato tubers were given to second and third instar grubs for feeding. Single grub was released in each cup and three replications were maintained having 15 grubs per replication.

Observations on grub mortality were recorded at weekly interval up to eight weeks as per method standardized under AINP on soil arthropod pests (Anonymous, 2009). The dead larvae were counted, transferred to new Petri dishes containing moistened filter paper and examined for another seven days for growth of fungal hyphae to confirm mycosis. Eight week mortality data were subjected to probit analysis and $\mathrm{LC}_{50}$ values were calculated as outlined by Finney (1971) and using computer based probit software. Corrected per cent mortality was calculated as per Abbott (1925) formula.

\section{RESULTS AND DISCUSSION}

The fungus infected grubs of Brahmina coriacea were collected from potato fields at Kheradhar $(1950 \mathrm{~m}$ amsl) in Sirmaur district of Himachal Pradesh. The cadavers of grubs were completely engulfed in white hyphae. 
Chandel et al. (2015) collected a total of 321 grubs of $B$. coriacea and out of which 20.2 per cent were found to be infected with fungus. In infections of adult beetles, the fungus often emerged from intersegmental joints. The fungus was isolated on PDA from field infected white grubs and after purification, was identified as $B$. brongniartii. The $B$. brongniartii was identified by its shorter conidiogenous rachis and ellipsoid conidia which measured 2-3×1.5-2.5 $\mu \mathrm{m}$ in size. Colonies on PDA grew quickly, and based on morphological features the fungus was categorized into two
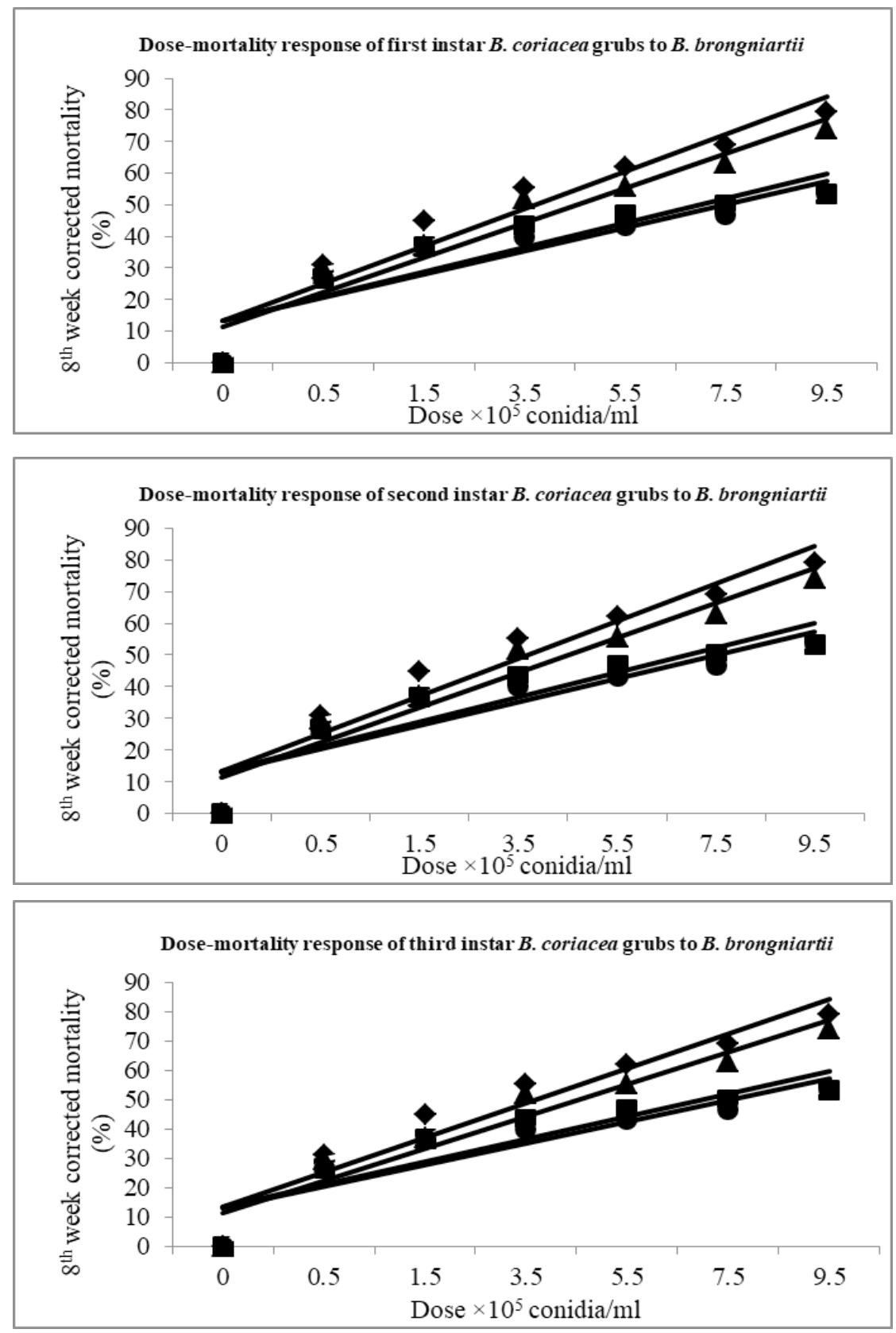

Fig. 1. Dose-mortality response of Brahmina coriacea grubs to Beauveria brongniartii.

-(KH I Dip treatment)

(KH I Oral feeding)

$\boldsymbol{\Delta}$ (KH II Dip treatm ent)

(KH II Oral feeding) 
isolates named as KH I and KH II. There was sparse growth of fungus in $\mathrm{KH} \mathrm{I}$ and in $\mathrm{KH}$ II isolate the growth was very dense. The colony colour in KH II was pure white, whereas in KH I the colony colour was off white. Kalia (2013) revealed that wide variation exists among the isolates of $B$. brongniartii in Himachal Pradesh and has characterized 7 isolates which are clustered in separate subclade.

\section{Susceptibility of Brahmina coriacea grubs to Beauveria brongniartii}

B. coriacea completes its life cycle in one year and undergoes three larval stages in duration of 230-267 days from June-April. The first, second and third instars occupy 19-24 days, 20-26 and 211-217 days, respectively (Pathania and Chandel, 2017). The susceptibility of first, second and third instar grubs of $B$. coriacea to KH I and KH II isolates was tested using dip treatment and oral feeding methods.

\section{Dip treatment method}

Dip treatment of first instar grubs with $\mathrm{KH} \mathrm{I}$ and $\mathrm{KH}$ II isolates of $B$. brongniartii produced a mortality of 46.66 per cent at highest dose $\left(9.5 \times 10^{5}\right.$ conidia/ml $)$ after one week of treatment. However, after 8 weeks of treatment, the mortality varied from $33.33-80.00$ per cent in KH I and 36.6676.66 per cent in KH II isolate, respectively. Kalia (2013) also observed 66.67 and 76.67 per cent mortality of first instar grubs treated with $95 \times 10^{4}$ and $75 \times 10^{4}$ conidia/ml $(\mathrm{KH}$ I isolate of B. brongniartii) and 66.66 and 76.67 per cent mortality with KH II isolate at same dosage, respectively, which is in concordance with our results. Jayaramaiah and Veeresh (1983) reported that B. bassiana@109 spores $/ \mathrm{ml}$ produced 92.0 per cent mortality of first instar grubs of H. serrata. The $\mathrm{LC}_{50}$ value of $\mathrm{KH}$ I was $2.55 \times 10^{5}$ conidia/ $\mathrm{ml}$, and in $\mathrm{KH}$ II, the $\mathrm{LC}_{50}$ value was $2.80 \times 10^{5}$ conidia $/ \mathrm{ml}$. Khagta (2006) reported $\mathrm{LC}_{50}$ of $10^{7}$ conidia/ml of B. bassiana for first instar grubs of $B$. coriacea.

Against second instar grubs, dip treatment with $\mathrm{KH}$ I and KH II isolates caused 20.00 per cent and 16.67 per cent mortality, respectively, at lowest tested concentration $\left(0.5 \times 10^{5}\right.$ conidia $\left./ \mathrm{ml}\right)$ after one week of treatment. The mortality data at different dosages ranged between 23.33-60.00 per cent for both the isolates, after four weeks of treatment. After 8 weeks of treatment, the maximum mortality was 76.66 per cent in KH I, whereas in KH II, the mortality was recorded to be 73.33 per cent (Figure 1). Jayaramaiah and Veeresh (1983) reported that B. brongniartii @ $10^{9}$ spores/ $\mathrm{ml}$ caused 86.00 per cent mortality of second instar grubs of $H$. serrata. Sharma et al. (1999) inoculated second instar grubs of $H$. consanguinea by dipping in spore suspension of $2-4.5 \times 10^{6}$ conidia/ml and observed 100 per cent mortality with $B$. bassiana and B. brongniartii after 4-6 weeks of treatment. Kalia (2013) reported 46.67 per cent mortality with KH I $\left(29.5 \times 10^{4}\right.$ conidia $\left./ \mathrm{ml}\right)$ and 43.33 per cent mortality with KH II $\left(29.5 \times 10^{4}\right.$ conidia/ml $)$. The $\mathrm{LC}_{50}$ value for KH I was $2.91 \times 10^{5}$ conidia $/ \mathrm{ml}$ and $3.98 \times 10^{5}$ conidia $/ \mathrm{ml}$ for KH II (Table 1). Khagta (2006) calculated higher $\mathrm{LC}_{50}$ value of $9.886 \times 10^{5}$ conidia/ml of $B$. bassiana against second instar grubs of $B$. coriacea.

When third instar grubs were dip treated with varying dosages of $B$. brongniartii, the mortality data ranged from 16.66- 40.00 per cent (KH I) and 16.66- 46.66 per cent (KH II) at different dosages after one week of the treatment. After eight weeks of treatment, 63.33 per cent mortality with KH I and 60.00 per cent mortality with KH II was observed@7.5 $\times 10^{5}$ conidia/ml. Jayaramaiah and Veeresh (1983) reported that $B$. brongniartii at a dose of $10^{9}$ spores/ $\mathrm{ml}$ resulted in 80.0 per cent mortality in third instar grubs of H. serrata. The $\mathrm{LC}_{50}$ value for KH I was $4.47 \times 10^{5}$ conidia/ $\mathrm{ml}$ and $4.88 \times 10^{5}$ conidia/ml for $\mathrm{KH}$ II (Table 1 ). These $\mathrm{LC}_{50}$ values are almost similar with the values $\left(4.4 \times 10^{4}\right.$ conidia/ $\mathrm{ml}$ for $\mathrm{KH} \mathrm{I}$ and $6.23 \times 10^{5}$ conidia $/ \mathrm{ml}$ ) reported earlier by Kalia (2013). Khagta (2006) computed $\mathrm{LC}_{50}$ of $4.645 \times 10^{7}$ conidia/ml for third instar grubs of $B$. coriacea.

When different instar grubs of $B$. coriacea were compared for their sensitivity to KH I and KH II isolates of $B$. brongniartii, there was gradual decrease in response with increasing age. Overall, first instar grubs were found to be 1.14-1.42 times more sensitive than second instar grubs to KH I and KH II in dip treatment. Similarly, second instar grubs were 1.23-1.54 times more sensitive as compared to third instar grubs. When $\mathrm{LC}_{50}$ values of first instar grubs were compared to the third instar grubs, there was 1.741.87 fold increase in $\mathrm{LC}_{50}$ values indicating decrease in sensitivity with age of grubs. The increase in $\mathrm{LC}_{50}$ in relation to change of instars may be due to increase in size of larvae. The full fed first, second and third instar grubs of B. coriacea are 11.6, 20.7 and $30.9 \mathrm{~mm}$ in length (Chandel et al., 1995), and there is a growth increment of about 10 $\mathrm{mm}$ in each instar. Therefore, it seems possible that there is a proportional increase in $\mathrm{LC}_{50}$ values in relation to age and size of grubs. Busvuine (1971) also reported that larger, heavier animals require a large dose than smaller animals and a means of comparison is via body weight.

\section{Oral feeding method}

In case of oral feeding method, when first instar grubs were treated with Kheradhar strains of $B$. brongniartii, the mortality varied from 13.33-36.66 per cent in case of $\mathrm{KH}$ I, whereas KH II gave a mortality of 20.00-36.66 per cent at different doses after one week of treatment. The maximum mortality obtained in KH I and KH II after 8 weeks 
Table 1. Dose-mortality response of Brahmina coriacea grubs to Beauveria brongniartii

\begin{tabular}{|c|c|c|c|c|}
\hline $\begin{array}{l}\text { Treatment } \\
\text { methods/ isolates }\end{array}$ & $\begin{array}{l}\mathrm{LC}_{50} \\
\text { (conidia/ml) }\end{array}$ & $\begin{array}{l}95 \% \text { Fiducial limits } \\
(\text { conidia } / \mathrm{ml})\end{array}$ & $\begin{array}{l}\text { Slope } \\
\text { (b) }\end{array}$ & $\begin{array}{l}\text { Regression equation } \\
\text { (Y) }\end{array}$ \\
\hline \multicolumn{5}{|l|}{ First instar } \\
\hline $\begin{array}{l}\text { KH I } \\
\text { (Dip Treatment) }\end{array}$ & $2.55 \times 10^{5}$ & $1.26-4.17 \times 10^{5}$ & 1.007 & $3.5827+1.0074 x$ \\
\hline $\begin{array}{l}\text { KH II } \\
\text { (Dip Treatment) }\end{array}$ & $2.80 \times 10^{5}$ & $1.25-5.11 \times 10^{5}$ & 0.8599 & $3.7558+0.8599 x$ \\
\hline $\begin{array}{l}\text { KH I } \\
\text { (Oral feeding) }\end{array}$ & $7.27 \times 10^{5}$ & $3.18-516.9 \times 10^{5}$ & 0.5192 & $4.0355+0.5192 x$ \\
\hline $\begin{array}{l}\text { KH II } \\
\text { (Oral feeding) }\end{array}$ & $9.69 \times 10^{5}$ & $3.87-67.67 \times 10^{5}$ & 0.4731 & $4.0603+0.4731 x$ \\
\hline \multicolumn{5}{|l|}{ Second instar } \\
\hline $\begin{array}{l}\text { KH I } \\
\text { (Dip Treatment) }\end{array}$ & $2.91 \times 10^{5}$ & $1.66-4.73 \times 10^{5}$ & 0.9830 & $3.5604+0.9830 \mathrm{x}$ \\
\hline $\begin{array}{l}\text { KH II } \\
\text { (Dip Treatment) }\end{array}$ & $3.98 \times 10^{5}$ & $2.27-7.37 \times 10^{5}$ & 0.9926 & $3.4117+0.9926 x$ \\
\hline $\begin{array}{l}\text { KH I } \\
\text { (Oral feeding) }\end{array}$ & $5.36 \times 10^{5}$ & $2.48-37.55 \times 10^{5}$ & 0.6009 & $3.9612+0.6009 x$ \\
\hline $\begin{array}{l}\text { KH II } \\
\text { (Oral feeding) }\end{array}$ & $8.82 \times 10^{5}$ & $3.95-881.87 \times 10^{5}$ & 0.5945 & $3.8435+0.5945 x$ \\
\hline \multicolumn{5}{|l|}{ Third instar } \\
\hline $\begin{array}{l}\text { KH I } \\
\text { (Dip Treatment) }\end{array}$ & $4.47 \times 10^{5}$ & $2.70-8.52 \times 10^{5}$ & 0.9937 & $3.3605+0.9937 x$ \\
\hline $\begin{array}{l}\text { KH II } \\
\text { (Dip Treatment) }\end{array}$ & $4.88 \times 10^{5}$ & $2.84-10.61 \times 10^{5}$ & 0.9553 & $3.3873+0.9553 x$ \\
\hline $\begin{array}{l}\text { KH I } \\
\text { (Oral feeding) }\end{array}$ & $3.03 \times 10^{5}$ & $1.09-6.93 \times 10^{5}$ & 0.6948 & $3.9703+0.6948 x$ \\
\hline $\begin{array}{l}\text { KH II } \\
\text { (Oral feeding) }\end{array}$ & $5.14 \times 10^{5}$ & $2.53-22.14 \times 10^{5}$ & 0.6585 & $3.8734+0.6585 x$ \\
\hline
\end{tabular}

of treatment was 53.33 per cent at highest concentration of $9.5 \times 10^{5}$ conidia $/ \mathrm{ml}$. The $\mathrm{LC}_{50}$ value for $\mathrm{KH}$ I was calculated to be $7.27 \times 10^{5}$ conidia $/ \mathrm{ml}$ and $9.69 \times 10^{5}$ conidia $/ \mathrm{ml}$ for KH II. In second instar grubs, $\mathrm{KH}$ I and KH II isolates caused 16.67 per cent mortality at lowest concentration $\left(0.5 \times 10^{5}\right.$ conidia/ $\mathrm{ml}$ ) after one week of treatment. The mortality data at different dosages ranged between 30.00-60.00 per cent for KH I and 30.00-56.66 per cent for KH II, after 8 weeks of treatment. The $\mathrm{LC}_{50}$ value for $\mathrm{KH}$ I was computed to be $5.36 \times 10^{5}$ conidia/ml and $8.82 \times 10^{5}$ conidia $/ \mathrm{ml}$ for KH II.

When third instar grubs were subjected to oral feeding of $B$. brongniartii, the mortality varied from $16.66-40.00$ per cent at different doses after one week of treatment. At highest concentration of $9.5 \times 10^{5}$ conidia $/ \mathrm{ml}$, maximum mortality obtained for KH I was 66.66 per cent and 63.33 per cent for KH II after 8 weeks of treatment (Figure 1). The $\mathrm{LC}_{50}$ value for KH I was calculated to be $3.03 \times 10^{5}$ conidia $/ \mathrm{ml}$ and $5.14 \times 10^{5}$ conidia/ml for KH II (Table 1). Contrary to dip treatment, there was gradual increase in susceptibility with increase in age of the grubs. First instar grubs were 1.098-1.36 times less sensitive to treatment as compared to second instar grubs. A comparison of first instar grubs with third instar grubs revealed 1.89-2.39 fold lesser sensitivity of first instar grubs. The second instar grubs, were found to be 1.72-1.77 times less sensitive to third instar grubs on the basis of their calculated $\mathrm{LC}_{50}$ values in oral feeding tests. The higher sensitivity of third instar grubs in oral feeding is attributed to higher feeding potential of third instar grubs. The third instar grubs are most voracious feeders leading to more ingestion of conidia from treated tubers.

\section{Comparison of dip treatment and oral feeding method}

Against first and second instar, dip treatment of grubs in conidial suspension of $B$. brongniartii was found to be statistically at par with oral feeding method based on 95\% fiducial limits which showed distinct overlap (Table 1). However, $\mathrm{LC}_{50}$ value was calculated to be maximum $\left(9.69 \times 10^{5}\right.$ conidia/ml $)$ for $\mathrm{KH}$ II in oral feeding method against first instar grubs. Against second instar grubs, $\mathrm{KH}$ II (Dip treatment) was found to be 2.22 times effective. The $\mathrm{LC}_{50}$ value was calculated minimum in case of $\mathrm{KH} \mathrm{I}$ in dip treatment and it was found to be 3.80 times more virulent as compared to KH II (oral feeding). KH I (dip treatment) 
showed maximum virulence. Irrespective of isolates, dip treatment was 2.85-3.46 times more effective as compared to oral feeding method. Irrespective of method of treatment, isolate $\mathrm{KH}$ I was 1.10-1.33 times more virulent as compared to KH II. Against second instar grubs, KH II (dip treatment) was found to be 2.22 times more effective as compared to $\mathrm{KH}$ II (oral feeding). On the basis of $\mathrm{LC}_{50}$ value, it was 3.03 times more toxic as compared to $\mathrm{KH}$ II (oral feeding). Irrespective of isolates, dip treatment was 1.84 and 2.22 times more effective as compared to oral feeding method. Irrespective of method of treatment, isolate KH I was 1.37 and 1.65 times more virulent as compared to KH II. As opposed to younger instars of $B$. coriacea, the $\mathrm{LC}_{50}$ values were calculated to be on lower side in oral feeding method, although data were found to be statistically non-significant. The efficacy of $\mathrm{KH}$ $\mathrm{I}$ in oral feeding was 1.70 times higher as compared to $\mathrm{KH}$ II (oral feeding) which was least effective.

From the results, it can be concluded that method of treatment did not affect susceptibility of $B$. brongniartii in different instars of $B$. coriacea, but the susceptibility of younger instars was marginally higher than older instars. The susceptibility of insects to fungal infection is influenced by a number of factors, including pathogen, host properties and environmental conditions (Mullens, 1985; Benz, 1987; Fuxa and Tanada, 1987; Inglis et al., 2001). Developmental stage is an important factor that has been reported to affect host susceptibility to entomopathogenic fungi (Ferron, 1985; Dimbi et al., 2003). Yokoyama et al. (1998) also observed that younger instars of Anomala corpulenta Motschulsky are more sensitive than older instars to entomopathogenic fungi. The reason for this varying susceptibility is that the cuticle is the primary barrier to entomopathogenic infection of insects. It is likely that the structural components of the white grub cuticle change with increasing physiological age, resulting in changing susceptibility to infection (Nong et al., 2011). This suggests that bio control using entomopathogenic fungi will be more effective when applied at earlier stages of target pest.

\section{REFERENCES}

Abbott WS. 1925. Method for computing the effectiveness of an insecticide. J of Econ Entomol. 18: 265-267. https:// doi.org/10.1093/jee/18.2.265a

Anonymous. 2009. Annual Progress Report, 2008-09. All India Network Project on White Grubs and Other Soil Arthropods, Palampur, India.

Benz G. 1987. Environment. pp. 177-214, In: Fuxa J R, and Tanada Y (Eds.). Epizootiology of Insect Diseases, John Wiley and Sons, New York.
Busvuin JR. 1971. A critical review of the techniques for testing insecticides. Commonwealth Agric Bur, Dorchester, UK.

Chandel RS, Chandla VK, Sharma A. 2003. Population dynamics of potato whitegrubs in Shimla hills. J Indian Potato Assoc. 30: 151-152.

Chandel RS, Gupta PR, Chander R. 1995. Behaviour and biology of the defoliating beetle, Brahmina coriacea (Hope) (Coleoptera: Scarabaeidae) in Himachal Pradesh. J Soil Biol Ecol. 15(1): 82-89.

Chandel RS, Pathania M, Verma KS, Bhatacharyya B, Vashisth S, Kumar V. 2015. The ecology and control of potato whitegrubs of India. Potato Res. 58: 147-164. https://doi.org/10.1007/s11540-015-9295-3

Chandel RS, Pathania M, Verma KS, Mehta PK. 2015b. Abundance and diversity of whitegrubs in different farming areas of Himachal Pradesh. Souvenir XVIII Group Meeting of All India Network Project on Soil Arthropod Pests, CSKHPKV Palampur, H.P., India, pp. 10-14.

Dimbi S, Maniania, NK, Lux SA, Mueke JM. 2003. Host species, age and sex as factors affecting the susceptibility of the African tephritid fruit fly species, Ceratitis capitata, $C$. cosyra and $C$. fasciventris to Infection by Metarhizium anisopliae. J Pest Sci. 76: 113-117. https:// doi.org/10.1007/s10340-003-0006-5

Ferron P. 1985. Fungal Control. pp. 313-346. In: Kerkut G.A. and Gilbert L.I. (Eds.). Comparative Insect Physiology, Biochemistry and Pharmacology. vol. 12, Pergamon Press, Oxford, UK.

Finney DJ. 1971. Probit Analysis. pp. 333. Third edition, Cambridge University Press, Cambridge, London, UK.

Fuxa JR, Tanada Y. 1987. Epizootiology of Insect Diseases. New York, NY: John Wiley and Sons.

Gupta RBL. 2001. Fungal pathogens in the management of whitegrubs and other soil dwelling pests. In: Sharma G, Mathur YS, Gupta RBL (Eds.) Indian Phytophagous Scarabs and their Management, Agrobios India.

HajekAE, St. Leger RJ. 1994. Interactions between fungal pathogens and insect hosts. Annu Rev Entomol. 39: 293-322. https://doi.org/10.1146/annurev.en.39.010194.001453

Inglis GD, Goettel MS, Butt TM, Strasser H. 2001. Use of Hyphomycetes fungi for managing insect pests, pp. 23-69, In: Butt T.M., Jackson C W, and Magan 
SAURBH SONI et al.

N (Eds.). Fungi as Biocontrol Agents: Progress, Problems and Potential, CABI International/ AAFC, Wallingford, United Kingdom. https://doi. org/10.1079/9780851993560.0023

Jairamaiah M, Veeresh GK. 1983. Studies on the symptoms of infection caused by new silkworm white muscardiane fungus, Beauveria brongniartii (Sacc.) Petch of different stages of the whitegrub Holotrichia serrata F. (Coleoptera: Scarabaeidae). J Soil Biol Ecol. 3: 7-12.

Kalia M. 2013. Characterization and evaluation of entomopathogenic fungi associated with whitegrubs in Himachal Pradesh. Ph.D Thesis, Department of Entomology, CSK Himachal Pradesh Krishi Vishvavidyalya, Palampur, India.

Khagta R. 2006. Evaluation of some entomopathogenic fungi for the suppression of Brahmina coriacea (Hope) M.Sc. Thesis, Department of Entomology University of Horticulture and Forestry, Nauni, India.

Leathers TD, Gupta SC, Alexander NJ. 1993. Mycopesticides: Status, challenges and potential. J Ind Microbiol. 12: 69-75. https://doi.org/10.1007/BF01569904

Misra SS, Chandel RS. 2003. Potato whitegrubs in India, pp. 47. Technical Bulletin no. 60, Central Potato Research Institute, Shimla, Himachal Pradesh.

Misra SS. 2000. Whitegrubs, pp. 57-60. In: Khurana P (Ed.). Diseases and Pests of potato, a manual. Central Potato Research Institute, Shimla. PMid:10771161

Mullens BA. 1985. Host age, sex, and pathogen exposure level as factors in the susceptibility of Musca Domestica to Entomophthora muscae. Entomol Exp Appl. 37: 33-39. https://doi.org/10.1111/j.1570-7458.1985.tb03449.x
Nong X, Liu C, Lu X, Wang Q, Wang G, Zhang Z. 2011. Laboratory evaluation of entomopathogenic fungi against the whitegrubs, Holotrichia oblita and Anomala corpulenta (Coleoptera: Scarabaeidae) from the field of peanut, Arachis hypogaea. Biocont Sci Technol. 21: 593603. https://doi.org/10.1080/09583157.2011.566324

Pathania M, Chandel R S. 2017. Life history strategy and behaviour of white grub, Brahmina coriacea (Hope) (Coleoptera: Scarabaeidae: Melolonthinae) an invasive pest of potato and apple agro-ecosystem in northwestern India. Oriental Insects 51: 46-69. https://doi.org/10.108 0/00305316.2016.1247756

Sharma S, Gupta RBL, Yadava CPS. 1999. Mass multiplication and formulation of entomopathogenic fungi and their efficacy against whitegrubs. J Mycol Pl Pathol. 29: 299-305.

Srikanth J, Easwaramoorthy S, Santhalakshmi G. 2010. Field efficacy and persistence of Beauveria brongniartii (Sacc.) Petch applied against Holotrichia serrata F. (Coleoptera: Scarabeidae) infecting sugarcane in Southern India. Sugarcane International 28: 151-156.

Veeresh GK. 1988. Whitegrubs, pp. 243-282. In: Veeresh G K and Rajgopal D (Eds.). Applied Soil Biology and Ecology, Second Edition, IBH, New Delhi.

Yokoyama T, Hasegava M, Fujiie A, Sawada M, Noguchi K. 1998. Microbial control of scarab beetle larvae by formulation of Metarhizium anisopliae (Deuteromycotina- Hyphomycetes) in a sweet potato field. Appl Entomol Zool. 33: 215-218. https://doi. org/10.1303/aez.33.215 